\title{
PENGARUH LITERASI DIGITAL TERHADAP KETERAMPILAN SOSIAL DALAM PEMBELAJARAN IPS PADA PESERTA DIDIK KELAS IX SMP ISLAM AL AZHAR 29 SEMARANG
}

\section{Adila Bunga Mewangi, Arif Purnomo, Asep Ginanjar}

Social Science Education Department, Faculty of Social Science, Universitas Negeri Semarang, Indonesia

\section{Info Artikel}

\section{Sejarah Artikel:}

DisubmitDesember 2019

Direvisi: Januari 2020

Diterima: Februari2020

\section{Keywords:}

Digital Literacy; Social Skills; Social Learning.

\begin{abstract}
Abstrak
Penelitian ini bertujuan untuk mengetahui pengaruh literasi digital terhadap keterampilan sosial dalam pembelajaran IPS pada peserta didik kelas IX SMP Islam Al Azhar 29 Semarang.Latar belakang penelitian ini adalah adanya perubahan pada pola pembelajaran di kelas menuju digital learningsehingga memengaruhi habitus peserta didik, salah satunya pada aspek keterampilan sosial. Metode yang digunakan dalam penelitian ini adalah kuantitatif dengan pendekatan ex post facto. Sampel yang digunakan sebanyak 37 peserta didik kelas IX SMP Islam Al Azhar 29 Semarang yang dipilih menggunakan metode random sampling. Pengumpulan data dilakukan dengan menggunakan angket, dokumentasi, dan observasi. Hasil penelitian menunjukkan bahwa terdapat pengaruh positif literasi digital terhadap keterampilan sosial peserta didik kelas IX dalam pembelajaran IPS di SMP Islam Al Azhar 29 Semarang, yang ditunjukkan dengan nilai koefisien korelasi sebesar 0,652 , nilai koefisien determinasi sebesar 0,426 dengan nilai persamaan regresi $\ddot{\bar{Y}}=26,824+0,707 \mathrm{X}$.
\end{abstract}

\begin{abstract}
The aim of this study is to analyze the effects of digital literacy on social skills in social learning at nineth grade students of SMP Islam Al Azhar 29 Semarang. This study is underlain by how technology is changing education patterns in classroom, so that it affects students' habitus, which one of them is social skills. The method of this study was quantitative research with ex post facto approach. Thirty seven students of nineth grade students in SMP Islam Al Azhar 29 Semarang were choosen to be sample by random sampling method. Data collection is done through questionnaire, documentation and observation. The result of this study showed that there was a positive effect of digital literacy on social skills in social learning at nineth grade students of SMP Islam Al Azhar 29 Semarang which was indicated by a correlation coefficient value 0,652, the coefficient of determination value 0,426 with regression equation value $\frac{\hat{Y}}{=}=26,824+0,707 X$.
\end{abstract}

(C) 2020 Universitas Negeri Semarang 


\section{PENDAHULUAN}

Kemajuan era globalisasi telah memberikan pengaruh yang signifikan terhadap kehidupan manusia. Hilangnya batas-batas antar negara mampu menghadirkan kemudahan transfer informasi dan teknologi dari satu negara ke negara lainnya. Salah satu dampaknya adalah perubahan pemanfaatan internet, baik dari segi pelaku maupun perilakunya. Berdasarkan survei yang dilakukan oleh Asosiasi Penyelenggara Jasa Internet Indonesia (APJI) pada tahun 2018, penetrasi pengguna internet pada kelompok usia 10-14 tahun mencapai 66,2\% sedangkan pada kelompok umur 15-19 tahun telah mencapai $91 \%$. Data tersebut menunjukaan adanya demand yang tinggi dari kelompok usia pelajar terhadap akses informasi yang luas dan cepat. Kondisi ini secara tidak langsung menuntut peserta didik memiliki kemampuan untuk memilah konten dan informasi yang mereka dapat melalui jaringan internet atau biasa disebut dengan literasi digital.

Sejalan dengan itu, Taylor dan Ward (1999: 18) menyebutkan bahwa "Jaringan komputer... meningkatkan interaksi komunkatif di antara peserta didik, guru dan bahkan melahirkan perubahan praktik sosiokultural". Sebagai contoh, dalam bebeberapa dekade terakhir, literasi selalu dikaitkan dengan angka melek huruf, dimana kemampuan tersebut dijadikan dasar untuk memperoleh dan meneruskan informasi. Seiring dengan berkembangnya teknologi, maka dasar-dasar seperti itu akan terganti dengan keterampilanketerampilan baru seperti pengoperasian komputer dan akses digital. Dengan demikian dapat disimpulkan jika peningkatan teknologi dapat merubah fondasi praktik sosial.

Chaeruman (2008:5-6) pembelajaran berbantu digital memungkinkan terjadinya proses belajar yang aktif, konstruktif, kolaboratif, antusias, dialogis, konstektual, reflektif, multisensory (melalui berbagai modalitas belajar atau panca indra), dan high order thingking skills training (kemampuan berpikir tingkat tinggi) seperti pemecahan masalah dan pengambilan keputusan. Hal ini berarti literasi digital mampu digunakan sebagai pemantik komunikasi antar peserta didik, maupun peserta didik dengan guru. Melalui komunikasi ini peserta didik mampu mengaktualisasikan diri dan pengetahuannya dalam kehidupan sosial sehingga pembelajaran menjadi lebih efektif dan efisien.

Dalam kaitannya dengan pembelajaran IPS, literasi digital menjadi salah satu pendukung untuk mengembangkan pengetahuan peserta didik terhadap isu-isu sosial yang terjadi di masyarakat secara real-time. Hal ini juga sejalan dengan konsep pembelajaran IPS yang menjadikan kehidupan manusia sebagai pokok kajian. Hakikat kehidupan manusia yang bersifat dinamis, tidak pernah berhenti, melainkan selalu aktif, dan menuntut pembaharuan dalam setiap proses pembelajaran. Sehingga, dibutuhkan kemudahan dalam akses informasi dan pengetahuan untuk efektivitas pembelajaran IPS. Melalui hal tersebut, peserta didik mampu mengembangkan aspek kognitif, keterampilan dan bahkan sikap mereka. Salah satunya adalah keterampilan sosial. SingerCalifano (2008:6) menjelaskan bahwa pemanfaatan teknologi digital berpengaruh terhadap keterampilan sosial peserta didik melalui meningkatkan kemampuan adaptif, pemecahan masalah melalui observasi, serta kemampuan transfer peran dalam ke dalam dunia nyata.

Warsita (2008: 144) dalam bukunya yang berjudul Teknologi Pembelajaran, Landasan dan Aplikasinya, mengungkapkan bahwa penggunaan internet untuk keperluan pembelajaran dan literasi semakin meluas terutama di negara- negara maju. Di Indonesia, digitalisasi literasi pada sekolah tingkat dasar dan menengah dimulai sejak tahun 2016 melalui Gerakan Literasi Nasional dengan program khusus di sekolah yakni Gerakan Literasi Sekolah. Implementasi gerakan literasi digital sekolah secara mandiri dapat dikembangkan model literasi dan pembelajaran digital yang disesuaikan dengan daya dukung sekolah. Salah satunya model pengembangan literasi digital yang diterapkan di SMP Islam Al-Azhar 29 Semarang yang menggunakan platform Google Classroom. 
Berdasarkan uraian diatas dapat diketahui bahwa perubahan berbagai aspek dalam pembelajaran khususnya yang berkaitan dengan teknologi dapat mengubah pola kegiatan di dalam kelas. Pola-pola ini secara lebih jauh dapat membentuk kebiasaan dan perilaku peserta didik. Hal ini yang melatarbelakangi peneliti melakukan penelitian dengan judul "Pengaruh Literasi Digital terhadap Keterampilan Sosial dalam Pembelajaran IPS pada Peserta Didik Kelas IX SMP Islam Al Azhar 29 Semarang."

\section{METODE}

Metode yang digunakan dalam penelitian ini adalah kuantitatif. Desain dari penelitian ini adalah Ex Post Facto Design.Jumlah sampel dalam penelitian ini maka peneliti menggunakan perhitungan yang dikembangkan Slovin. Sample dalam penelitian ini diambil dari populasi peserta didik kelas IX SMP Islam Al Azhar 29 Semarang yang berjumlah 58 orang. Untuk mendapatkan

Teknik pengumpulan data yang digunakan dalam penelitianini adalalah angket, dokumentasi, dan observasi. Angket dibagikan melalui Google Formulir. Adapun data-data yang diumpulkan melalui dokumentasi adalah daftar nama peserta didik, jurnal sikap, foto kegiatan dan materi literasi online. Sementara observasi dialkukan untuk mendukung data yang didapat dari metode angket, khsusunya pada variabel keterampilan sosial.

\section{HASIL DAN PEMBAHASAN}

\section{Uji Normalitas}

Penelitian ini menggunakan uji normalitas untuk membuktikan bahwa data yang digunakan berdistribusi normal. Pengujian ini menggunakan taraf siginifikansi sebesar 0,05 sehingga data dinyatakan berdistribusi normal jika nilai signifikansi lebih dari 0,05 .

Tabel 1.Hasil Uji Normalitas

$\begin{array}{r}\hline \text { One-Sample Kolmogorov-Smirnov Test } \\ \text { A. Unstandardized } \\ \text { Residual } \\ \hline\end{array}$

\begin{tabular}{ccr}
\hline & & 37 \\
$\begin{array}{c}\text { Normal } \\
\text { Parameters }\end{array}$ & $\begin{array}{c}\text { Mean } \\
\text { Std. } \\
\text { Deviation }\end{array}$ & $0 \mathrm{E}-7$ \\
Most & Absolute & 4,98151880 \\
Extreme & Positive &, 122 \\
Differences & Negative &, 066 \\
&,- 122 \\
Kolmogorov-Smirnov Z &, 743 \\
Asymp. Sig. (2-tailed) &, 640 \\
\hline \multicolumn{2}{c}{ a. Test distribution is Normal. }
\end{tabular}

Sumber: Data penelitian, Juli 2019

Berdasarkan hasil uji normalitas dapat disimpulkan bahwa $\mathrm{H}_{0}$ diterima karena nilai Sig. adalah 0,15 yang lebih besar dari nilai (alpha).

\section{Uji Homogenitas}

Uji homogenitas dilakukan untuk menguji sama tidaknya variansi-variansi dalam dua buah distribusi atau lebih. Dasar pengambilan keputusan uji homogenitas jika nilai sig. $>0,05$ bermakna distribusi data homogen.

Tabel 2.Hasil Uji Homogenitas

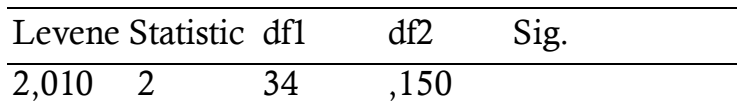

Sumber: Data penelitian, 2019

Berdasarkan tabel diatas, nilai sig. 0,15> 0,05 . Nilai tersebut bermakna variabel independen secara signifikan tidak memengaruhi variabel dependen. Sehingga dapat disimpulkan bahwa model regresi ini bersifat homogen.

\section{Uji Regresi Linear Sederhana}

Berdasarkan hasil uji regresi linear sederhana menggunakan SPSS 20 dapat diketahui hasil regresi sederhana seperti dalam tabel 3 dan 4.

Tabel 3. Nilai Korelasi dan Koefisien Determinasi

\begin{tabular}{ccccc}
\multicolumn{4}{c}{ Model Summary } \\
\hline Model & $\mathrm{R}$ & $\mathrm{R}$ & Adjusted R & Std. Error \\
& & Square & Square & of the \\
& & & & Estimate \\
\hline
\end{tabular}




\begin{tabular}{lllll}
\hline 1 &, $652^{\mathrm{a}}$ &, 426 &, 409 & 5,05218 \\
\hline
\end{tabular}

a. Predictors: (Constant), Literasi Digital Sumber: Data penelitian, 2019

Melalui tabel 3 diketahui bahwa nilai $\mathrm{R}$ (nilai korelasi) sebesar 0,652 dan nilai $\mathrm{R}$ square (koefisien determinasi) sebesar 0,426. Hal tersebut memiliki makna pengaruh literasi digital (X) terhadap keterampilan sosial (Y) adalah sebesar $42,6 \%$.

Tabel 4.Persamaan Regresi Linear Sederhana



a. Dependent Variable: Ketrampilan Sosial

Sumber: Data penelitian, Juli 2019

Dari tabel 4 diperoleh nilai konstanta (a) sebesar 26,824 dan nilai koefisien regresi (b) sebesar 0,707 . Hal ini bermakna jika variabel literasi digital sama dengan nol, maka variabel keterampilan sosial peserta didik sebesar 26,824. Selain itu, diperoleh pula nilai koefisien regresi (b) sebesar 0,707 yang bermakna jika variabel literasi digital mengalami kenaikan sebesar 1 poin maka variabel keterampilan sosial akan meningkat sebesar 0,707. Koefisien tersebut bersifat positif sehingga dapat dikatakan arah pengaruh variabel literasi digital (X) terhadap variabel keterampilan sosial $(\mathrm{Y})$ adalah positif.

\section{Literasi Digital}

Literasi digital peserta didik dalam penelitian ini terbagi kedalam 3 aspek yakni: a) kompetensi pemanfaatan teknologi; b) Memaknai dan menilai kredibilitas isi dan sumber literasi berbasis digital; c) Meneliti, mengonstruksi, dan mengomunikasikan informasi dan pengetahuan hasil literasi digital secara bertanggung jawab. Hal ini sejalan dengan komponen pendukung literasi digital yang dikemukakan oleh Bawden (dalam Munir 2017: 113-115) yang telah dijelaskan secara rincir pada landasan teori, yakni: a) pendukung literasi; b) pengetahuan latar belakang dunia informasi dan sifat sumber daya informasi; c) komponen utama; d) sikap dan prespektif.

Literasi digital peserta didik kelas IX di SMP Islam Al Azhar 29 Semarang cukup baik. Literasi digital peserta didik memiliki nilai indeks sebesar $67,42 \%$. Pada indikator kompetensi pemanfaatan teknologi, kemampuan peserta didik sudah baik. Kondisi ini dipengaruhi oleh beberapa hal seperti sarana dan prasarana sekolah serta kegiatan-kegiatan operasional untuk pembiasaan. Sarana dan prasarana sekolah terkait dengan digitalisasi literasi maupun pembelajaran pada dasarnya telah mendukung peningkatan kemampuan peserta didik terutama pada indikator kompetensi pemanfaatan teknologi. Pengadaan perangkat digital berupa tablet oleh pihak sekolah menuntut peserta didik untuk dapat mengoperasikan dan memanfaatkannya dalam proses pembelajaran

Sementara itu, pada indikator kemampuan meneliti, mengonstruksi, dan mengomunikasikan informasi dan pengetahuan hasil literasi digital secara bertanggung jawab masih berada pada kategori cukup baik. Sebagian besar peserta didik telah melakukan penulusuran lanjutan dengan membuka lebih dari dua sumber yang dilakukan untuk menguatkan informasi yang telah mereka temui sebelumnya. Begitupula pada indikator memaknai dan menilai kredibilitas isi dan sumber literasi berbasis digital yang berada pada kategori cukup baik. dari hasil penelitian dapat diketahui bahwa sebagian besar peserta didik belum mengetahui karakteristik situs sumber literasi digital yang kredibel atau dapat dipercaya. dari hasil penelitian dapat diketahui bahwa sebagian besar peserta didik belum mengetahui karakteristik situs sumber literasi digital yang kredibel atau dapat dipercaya.

\section{Keterampilan Sosial}


Keterampilan-keterampilan sosial yang dimiliki peserta didik tersebut sesuai dengan indikator keterampilan sosial yang dikemukakan oleh Caldarella dan Merrel (dalam Matson, 2009:4) yaitu peer relational skill; self management skill; academic skills; compliance skills; dan assertion skills.

Keterampilan sosial peserta didik kelas IX di SMP Islam Al Azhar 29 Semarang baik dengan nilai indeks sebesar 67,50\% dengan kategori cukup baik. Indikator dalam kerterampilan sosial yang telah berada pada kategori baik adalah peer-relational skills, academic skills, dan assertion skills. Sementara pada indikator self management skills dan compliance skills peserta didik kelas IX SMP Islam Al Azhar 29 Semarang, masih berada pada kategori cukup baik.

Aspek peer-relational skills peserta didik dapat dilihat dari sikap peserta didik yang mendengarkan penjelasan dari teman saat diskusi kelompok berlangsung yang sudah dilakukan hampir seluruh peserta didik. Mendengarkan penjelasan orang lain menjadi kunci dalam proses transfer informasi dalam komunikasi lisan. Sementara pada aspek selfmanagement skills pada poinpengaturan diri peserta didik untuk kemampuan memaparkan hasil diskusi dengan suara lantang adalah baik. Begitu pula pada poin kemampuan peserta didik dalam menanggapi kritikan dan saran dengan menggunakan bahasa yang baik dan benar.

Indikator variabel keterampilan sosial yang paling menonjol berada pada aspek academic skills. Bentuk dari keterampilan ini berupa kemampuan memahami penjelasan dan intruksi guru, kemampuan mengajukan pertanyaan yang sesuai dengan materi dan kemampuan membuat kesimpulan dari pembelajaran yang ketiganya memiliki kategori baik. Pada aspek compliance skills berkaitan dengan kemampuan peserta didik untuk patuh terhadap tata tertib yang berlaku dalam pembelajaran IPS. Sebagian besar peserta didik telah memahami ketentuan waktu dalam pembelajaran dan mampu memenuhi syarat tersebut. Namun pada poin ketertiban dalam penggunaan perangkat digital dalam kegiatan literasi pada pembelajran IPS banyak ditemui pelanggaran seperti membuka banyak jendela sehingga pada saat tidak dalam pengawasan guru, peserta didik membuka situs-situs yang tidak berkaitan dengan pembelajaran seperti Webtoon, Youtube dan sosial media Instagram. Sementara itu, indikator assertion skills atau keterampilan penegasan berguna dalam membentuk situasi belajar dan mengajar yang kondusif.Bentuk sikap dari indikator ini berupa kesadaran peserta didik untuk melaporkan kecurangan yang terjadi ataupun mengingatkan teman saat mengganggu proses pembelajaran telah mampu dilakukan.

\section{Pengaruh Literasi Digital terhadap Keterampilan Sosial}

Terdapat pengaruh positif literasi digital terhadap keterampilan sosial peserta didik kelas IX dalam pembelajaran IPS di SMP Islam Al Azhar 29 Semarang, yang ditunjukkan dengan nilai koefisien korelasi sebesar 0,652 , nilai koefisien determinasi sebesar 0,426 dengan nilai persamaan regresi $\mathrm{Y}=26,824+0707 \mathrm{X}$.

Pengaruh literasi digital terhadap keterampilan sosial peserta didik dapat dilihat pada penerimaan anggota kelompok, mendengarkan ketika peserta didik lain berbicara, pemberian apresiasi, keberanian meminta bantuan kepada guru, memahami instruksi dan penjelasan dari guru, kemampuan membuat kesimpulan, menyelesaikan tugas tepat waktu, dan menyanggah pertanyaan maupun pernyataan yang tidak sesuai dengan topik.

Berdasarkan hasil penelitian praktik literasi digital yang dilakukan belum dapat mengarahkan peserta didik untuk memberikan umpan balik pada hasil temuan yang dilakukan oleh pihak sekolah, sehingga proses komunikasi dua pihak yang terjalin secara digital dalam kegiatan literasi belum berlangsung. Hal ini yang kemudian memengaruhi poin kemampuan peserta didik untuk berkolaborasi dengan teman dalam melakukan pencarian informasi. Kolaborasi hanya terjadi pada batas-batas tertentu seperti pembagian tugas masing-masing anggota dan mengumpulkan hasil telaahnya, belum berada pada tahap mengkritisi hasil 
temuan masing-masing peserta didik dan saling menguatkan informasi yang ditemui. Sehingga mengakibatkan belum adanya kesadaran dan tanggung jawab untuk mengapresiasi hasil olah informasi orang lain, baik dalam jaringan maupun secara langsung. Meski begitu, pembiasaan untuk berkonsultasi dengan guru dalam proses literasi digital telah membentuk keberanian peserta didik untuk meminta bantuan kepada guru jika mengalami kesulitan. Pada proses konsultasi dengan guru, peserta didik meminta afirmasi, saran, dan koreksi guru terhadap hasil temuan informasi. Hal ini kemudian menimbulkan interaksi sosial yang memengaruhi perkembangan kepribadian peserta didik (Ahmadi, 2007:11).

Pengaruh literasi digital pada aspek academic skills dapat dilihat dari penggunaan sumber belajar melalui literasi digital yang lebih sering menggunakan studi kasus pada situs berita ataupun informasi lain yang mereka temui pada kegiatan literasi digital, sehingga peserta didik tidak hanya mengetahui sebuah konsep tetapi juga memiliki pemahaman yang faktual dan komprehensif untuk memahami instruksi dan penjelasan guru. Hal ini sejalan dengan pendapat menurut Hammersley (1990: 35) menunjukkan kecerdasan peserta didik melalui pemahaman pembelajaran yang konkrit yang diperlukan baik untuk memahami apa yang dimaksud oleh guru.

Pengaruh literasi digital terhadap aspek assertion skills pada keterampilan sosial dalam pembelajaran IPS berkaitan dengan kemampuan menyanggah pertanyaan atau pernyataan yang tidak sesuai dengan topik yang masih berada dalam kategori cukup baik. Hal ini sejalan dengan kemampuan pesera didik untuk menentukan topik pada pencarian informasi menggunakan perangkat digital yang masih berada pada batas bawah kategori cukup baik. Purwono (2008: 10) mengatakan, pemilihan kata kunci sesuai dengan topik yang diinginkan dengan menggali kata kunci apa saja yang bisa digunakan, dengan melihat cakupan subyek tersebut. Ketidakpahaman peserta didik akan topik yang dibahas, membuat peserta didik belum dapat memberikan batasan-batasan atas apa yang menjadi ranah pembahasan mereka.

Berdasarkan penjelasan tersebut maka pengaruh literasi digital terhadap keterampilan sosial peserta didik sesuai dengan terminologi literasi digital milik UNESCO (Kemendikbud, 2017:8) yakni literasi digital merupakan life skills yang tidak hanya berkaitan dengan kemampuan penggunaan perangkat teknologi informasi dan komunikasi, tetapi juga kemampuan bersosialisasi, kemampuan dalam pembelajaran, dan memiliki sikap, berpikir kritis, kreatif serta inspiratif.

\section{SIMPULAN}

Berdasarkan hasil penelitian dan pembahasan dapat disimpulkan: Literasi digital peserta didik kelas IX di SMP Islam Al Azhar 29 Semarang cukup baik. Literasi digital peserta didik memiliki nilai indeks sebesar $67,42 \%$. Keterampilan sosial peserta didik kelas IX di SMP Islam Al Azhar 29 Semarang baik dengan nilai indeks sebesar 67,50\% dengan kategori cukup baik.Terdapat pengaruh positif literasi digital terhadap keterampilan sosial peserta didik kelas IX dalam pembelajaran IPS di SMP Islam Al Azhar 29 Semarang, yang ditunjukkan dengan nilai koefisien korelasi sebesar 0,652, nilai koefisien determinasi sebesar 0,426 dengan nilai persamaan regresi $Y=26,824+0707 X$.Pengaruh literasi digital terhadap keterampilan sosial peserta didik dapat dilihat pada penerimaan anggota kelompok, mendengarkan ketika peserta didik lain berbicara, pemberian apresiasi, keberanian meminta bantuan kepada guru, memahami instruksi dan penjelasan dari guru, kemampuan membuat kesimpulan, menyelesaikan tugas tepat waktu, dan menyanggah pertanyaan maupun pernyataan yang tidak sesuai dengan topik. Namun pada indikator

Perlu diadakannya pelatihan oleh pihak sekolah dan yayasan secara independen maupun bekerja sama dengan kementerian terkait dan pihak swasta. Pelatihan tersebut bertujuan untuk meningkatkan literasi digital peserta didik khususnya untuk meningkatkan keterampilan 
dalam mengidentifikasi dan mengolah informasi digital secara optimal

\section{DAFTAR PUSTAKA}

Chaeruman, Uwes A. 2008. 'Mendorong Pemanfaatan E-Learning di Sekolah'. Makalah disajikan dalam Seminar Nasional The Power of ICT in Education, PPs UNJ, Jakarta, 15 April.

Hammersly, Martyn. 1990. Etnografi Ruang Kelas. Terjemahan Wasono.Semarang: IKIP Semarang Press.
Kemendikbud. 2017. Materi Pendukung Literasi Digital. Jakarta: Sekretariat Tim Gerakan Literasi Nasional.

Purwono. 2008. 'Penelusuran Informasi melalui Internet'. Makalah Seminar HJM Ilmu Pepurstakaan, Fakultas Adab dan Humaniora, uin Jakarta., 30 April.

Singer-Califano, Autumn. 2008. 'The Use of Technology in Enhancing Social Skills'. Dalam Imanager's Journal on Educational Psychology .Vol 1. No. 4. Hal.6.

Taylor, T., Ward, I. 1998. Literacy in The Age of The Internet. New York: Columbia University Press. 